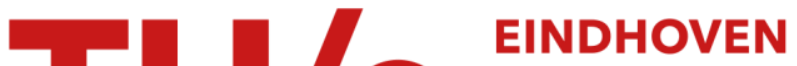 UNIVERSITY OF TECHNOLOGY
}

\section{Suspension kinematic analysis of UTeM's FV Malaysia electric vehicle racing car}

Citation for published version (APA):

Abdul Manaf, M. Z., Latif, M. F. A., Razak, M. S. A., Hassan, M. Z. B., \& Rosley, M. I. F. (2016). Suspension kinematic analysis of UTeM's FV Malaysia electric vehicle racing car. International Review of Mechanical Engineering (IREME), 10(4), 294-300. https://doi.org/10.15866/ireme.v10i4.8626

DOI:

10.15866/ireme.v10i4.8626

Document status and date:

Published: 01/01/2016

Document Version:

Publisher's PDF, also known as Version of Record (includes final page, issue and volume numbers)

Please check the document version of this publication:

- A submitted manuscript is the version of the article upon submission and before peer-review. There can be important differences between the submitted version and the official published version of record. People interested in the research are advised to contact the author for the final version of the publication, or visit the $\mathrm{DOI}$ to the publisher's website.

- The final author version and the galley proof are versions of the publication after peer review.

- The final published version features the final layout of the paper including the volume, issue and page numbers.

Link to publication

\section{General rights}

Copyright and moral rights for the publications made accessible in the public portal are retained by the authors and/or other copyright owners and it is a condition of accessing publications that users recognise and abide by the legal requirements associated with these rights.

- Users may download and print one copy of any publication from the public portal for the purpose of private study or research.

- You may not further distribute the material or use it for any profit-making activity or commercial gain

- You may freely distribute the URL identifying the publication in the public portal.

If the publication is distributed under the terms of Article 25fa of the Dutch Copyright Act, indicated by the "Taverne" license above, please follow below link for the End User Agreement:

www.tue.nl/taverne

Take down policy

If you believe that this document breaches copyright please contact us at:

openaccess@tue.nl

providing details and we will investigate your claim. 


\title{
Suspension Kinematic Analysis of UTeM's FV Malaysia Electric Vehicle Racing Car
}

\author{
Muhammad Zaidan Abdul Manaf, Mohd Faruq Abdul Latif, Mohd Suffian Ab Razak, \\ Muhammad Zahir Hassan, Mohd Idain Fahmy Rosley
}

\begin{abstract}
The purpose of this paper is to investigate the kinematic performance of students' racing car, namely UTeM's FV Malaysia Electric Vehicle. An elasto-kinematic analysis approach is used to predict the car's performance during straight line drive and curvature drive. Two suspension design factors involved in this analysis are toe and camber. The kinematic analysis is iterated using the multibody dynamics simulation. The suspension performance is then compared to the standard SLA suspension.

The result shows that the front suspension design does not follow the good $C$ shaped toe and camber curves for the SLA suspension type. However, the suspension design of the rear suspension performs well as it follows the good SLA performance curve. Copyright C 2016 Praise Worthy Prize S.r.l. - All rights reserved.
\end{abstract}

Keywords: Suspension Kinematic, Multibody Dynamics Analysis, Suspension Design Factor

\section{Nomenclature}

FV Malaysia Formula Varsity Malaysia

UTeM Universiti Teknikal Malaysia Melaka

FVEV FV Electric Vehicle Racing Car

WVD Wheel vertical displacement

SLA Short-long arm

CAD Computer-aided design

MBD Multibody dynamics

SDF Suspension design factor

CAE Computer-aided engineering

\section{Introduction}

FV Malaysia is a platform for university and technical institute students in Malaysia and the Asian region to show their capabilities in designing and developing small-scale racing cars.

In this current edition, the new category of powertrain has been introduced, which is an electric motor powertrain that makes the racing car achieve its full electrical vehicle capability.

The event was held at Sepang International Circuit (South Track), Malaysia, which is made up of eight tight turns with a total length of $2.6 \mathrm{~km} \mathrm{[1].} \mathrm{The} \mathrm{car} \mathrm{reported}$ in this paper with the call sign of FVEV is propelled by a $3 \mathrm{~kW}$ brushless DC electric motor that features regenerative energy braking. The vehicle handling performance must be well designed to ensure stability during high speed cornering. Therefore, it is critical to investigate the suspension performance as the car handling is directly proportional to the suspension characteristics of the car itself [2]-[10]. In order to obtain the suspension performance data of the real car, a special
Kinematic and Compliance measurement machine must be used. However, this machine is not available at the research facility, therefore, another method of analyzing the suspension performance is suggested. The proposed method used computer simulation, which investigated the multibody dynamics of the suspension and car body during racing.

This is the simulation type analysis that gives a $90 \%$ accurate result to the actual car performance [11].

The kinematic analysis of the vehicle suspension behaviour becomes a challenging issue due to its nonlinear asymmetric characteristics [12], [13].

It is commonly analyzed. The common suspension design factors in the suspension analysis are camber, roll, and toe [8], [12]-[15].

A study by Kakria and Hsu showed that a computerbased simulation can be used to perform a complex kinematic analysis [16], [17].

There are several tools that could enhance the process of suspension design. One of them is an elasto-kinematic analysis that can be used to predict the camber angle, castor angle, toe, kingpin angle, roll center position, damper ratio, spring ratio, track change, wheel-base change, brake steer, lateral force steer, and other parameters used in designing the suspension [15].

A recent tool used in suspension development is the CAE method, which simulates the suspension's MBD under specific driving conditions [18]-[19].

The objective of the paper is to investigate the kinematic performance of the racing car suspension system. These include SDF and forces acting on the wheels. The result is then compared to the standard SLA type suspension to verify that the suspension design follows the standard SLA performance curve. 


\section{Methodology}

The analysis process started with the design of the static and dynamic suspension 2D layouts using CAD. Then, the team measured the suspension hard points from the actual car (Section II.1). This data is then used to model the car in the multibody dynamics (MBD) environment. The software used in this simulation is Altair Motion View (discussed in detail in Section III).

\section{II.1. Suspension Parameter \& Configuration}

The car used the SLA suspension type for both front and rear suspensions. A push rod configuration was selected for the spring and absorber system.

The advantage of the push rod configuration is that it removed the clutter of the spring and absorber on the conventional configuration that can reduce the aerodynamics performance. This car is matched with a 14 " alloy rim and fitted with a R14 165/55 semi slick tire with an inner rim orientation. The process started by generating a 2D suspension geometry layout as shown in Figs. 1 and 2. From this layout, the maximum static camber for the front and rear suspensions are 3.10 degree and 3.04 degree, respectively. In order to simplify the fabrication process, the lower and upper control arm designs are made identical. The rod end device is used to achieve the desired suspension design factor.

This length of the device can be adjusted to set the desired lateral position of the lower and upper ball joints.

It can be screwed in and out to the maximum length of $20 \mathrm{~mm}$. The parameter of the car and suspension are shown as in Table I and Table II.

\section{II.2. MBD Modeling}

Some of the points cannot be measured accurately from an actual car, hence the CAD model is used.

The CAD model is developed in the early stage as a guideline in the fabrication process. The data from direct measurements and CAD extracted data are then modelled in the Altair Motionview software environment.

The car model is developed using a built-in software template for the SLA type suspension. The model consists of complete vehicle components, namely steering system, chassis (ground body), powertrain, SLA suspension, and wheel (Figs. 5(a), (b)). This software allows users to give input of the car's parameters in a special vehicle template tab. An SLA (short long arms) type arrangement is used to induce a negative camber during the wheel travel. During cornering, it helps in getting the positive camber gain on the lightly loaded inside wheel, while the heavily loaded outside wheel gains negative camber. These will offset the effect of body roll and maintain the optimal wheel camber [16].

Each arm has two mounting points to the chassis and one joint at the knuckle. The coil spring over the shock absorber is mounted to the bell crank to control the vertical movement.
Two sources of hard point data ensure the optimum kinematic modelling process. It can also be used as a guide to improve the suspension design.

Even though this analysis used a built-in MBD kinematic analysis setting, there are standard assumptions to simplify the model. The link is assumed to be rigid, therefore, a linear analysis can be performed.

These assumptions must be made in order to lower the calculation time and to simplify the model [20]-[23].

However, the details of the mathematic equations are not discussed in this paper, since it is not the main interest of this paper. A series of kinematic tests (ride test and roll test) and kinetic tests (force analysis) are performed on the car model [24].

The kinematic performance of camber and toe is tested in the ride test, while the car's roll stability is tested in the roll test [25].

TABLE I

CAR SIZE AND SUSPENSION PARAMETERS

\begin{tabular}{cc}
\hline \hline Parameter & Data \\
\hline Front wheel track & $1350 \mathrm{~mm}$ \\
Rear wheel track & $1450 \mathrm{~mm}$ \\
Wheelbase & $1600 \mathrm{~mm}$ \\
Front and rear jounce & $50 \mathrm{~mm}$ \\
Front and rear rebound & $50 \mathrm{~mm}$ \\
Front and rear droop travel & $100 \mathrm{~mm}$ \\
\hline \hline
\end{tabular}

TABLE II

CONTROL ARM SIZING FOR FRONT AND REAR SUSPENSIONS

\begin{tabular}{ccc}
\hline \hline Control arm parameter & Front suspension & Rear suspension \\
\hline Upper lateral width & $210 \mathrm{~mm}$ & $402.5 \mathrm{~mm}$ \\
Lower lateral width & $220 \mathrm{~mm}$ & $412.5 \mathrm{~mm}$ \\
Upper long. width & $360 \mathrm{~mm}$ & $360 \mathrm{~mm}$ \\
Lower long. width & $360 \mathrm{~mm}$ & $360 \mathrm{~mm}$ \\
A-arm angle & 78.6 degree & 47.1 degree \\
\hline \hline
\end{tabular}

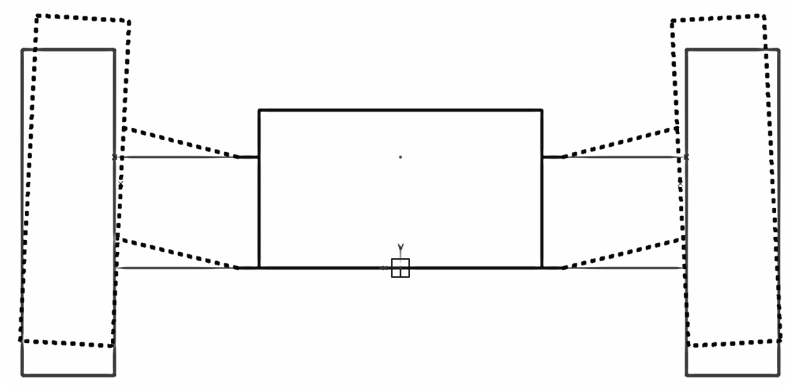

Fig. 1. 2D layout of front suspension showing static camber (solid line) and dynamic camber (dotted line)

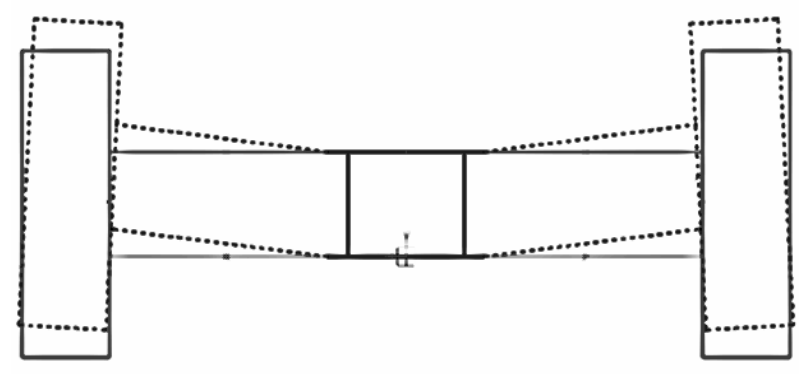

Fig. 2. 2D layout of rear suspension showing static camber (solid line) and dynamic camber (dotted line) 


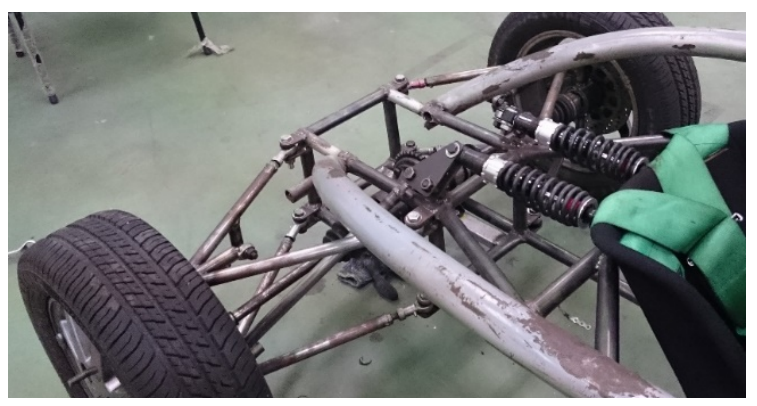

Fig. 3. Push rod configuration for rear suspension

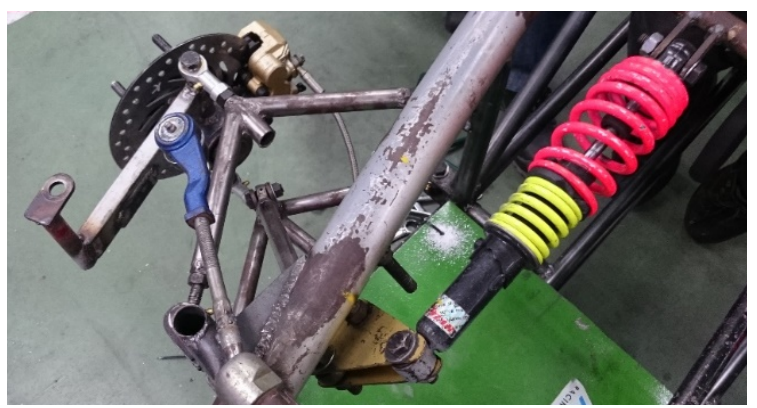

Fig. 4. Push rod configuration for front suspension

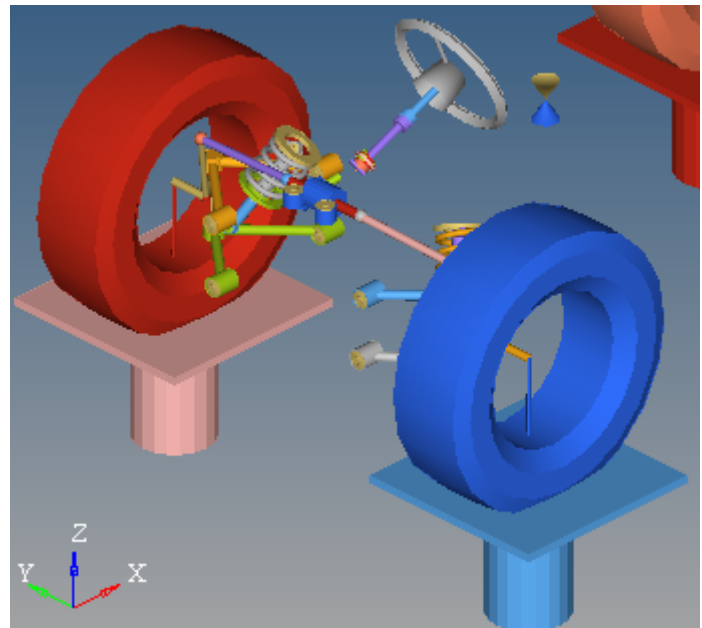

Fig. 5(a). MBD model of racing car - front suspension

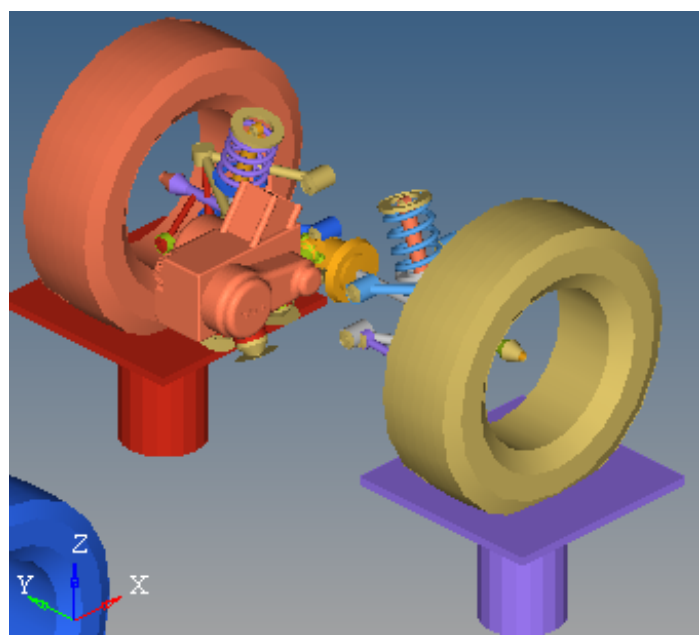

Fig. 5(b). MBD model of racing car - rear suspension

\section{II.3. Kinematic Analysis}

Ride test analysis - In this analysis, an initial steering input is applied to the model while keeping the wheel in the centre position at the static vehicle height. Then, the left and right suspensions are moved to jounce the height simultaneously. Next, the suspension is moved to rebound the height and finally to return to its static height. This test focuses on the effect of toe and camber angles to the vertical movement of the wheel. Roll test analysis - In this test, an initial steering input is applied to the vehicle model, and simultaneously, the suspension is moved to the initial static wheel position. Then, the left and right rolling movements are initiated, in which equal magnitude displacements in the opposite direction are applied. This test focuses on the effect of toe and camber angles to the body roll angle. Force analysis - In this analysis, the forces acting on each wheel are calculated.

The test distributes the vertical force evenly on all four wheels. This data is important in knowing the structure integrity of the suspension components and the chassis itself. Commonly, this force data is passed on to the structure integrity team to be used in their analysis.

\section{Result}

The suspension design factor simulation result is discussed in this section, which includes toe analysis, camber analysis, roll analysis, and force on wheel.

\section{III.1. Toe Analysis}

The changes of the toe angle due to the vertical wheel movement are shown in Figs. 6. Figs. 6(a) and 6(b) show the toe data for the front left wheel and front right wheel, while Figs. 6(c) and 6(d) show the toe data of the rear left wheel and rear right wheel. Both left and right front wheels show similar toe data. During static height, the toe value is $-0.13^{\circ}$ (toe in). This means the frontal distance of the front wheel is closer to the rear-end distance of the front wheel. During maximum jounce and rebound, the toe value increased to $2.00^{\circ}$ angle (toe out) and $-0.13^{\circ}$ (toe in), respectively. For the rear wheel, the toe curve mirrored the toe curve of the front wheel.

The maximum jounce, maximum rebound, and static height toe values are $1.13^{\circ}$ (toe out), $2.5^{\circ}$ (toe out), and $0.38^{\circ}$ (toe out) respectively. The toe for the rear wheel shows a good $\mathrm{C}$ shape performance curve. It fits the SLA objective, which is to ensure that the lightly loaded wheel gains a positive camber, while the heavily loaded wheel gains a negative chamber. However, for the front wheel, the negative slope curve does not fit the SLA objective. Both lightly and heavily loaded wheels showed positive and negative cambers during rebound and jounce, respectively.

\section{III.2. Camber Analysis}

The camber vs wheel vertical displacement is shown in Figs. 7. 


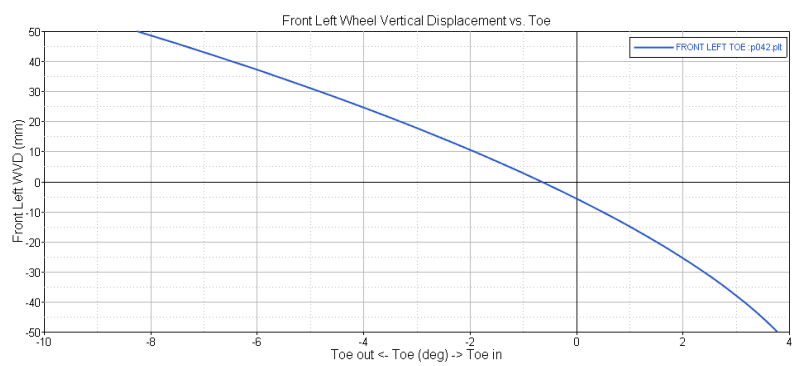

(a) Front left wheel vertical displacement (WVD) vs toe

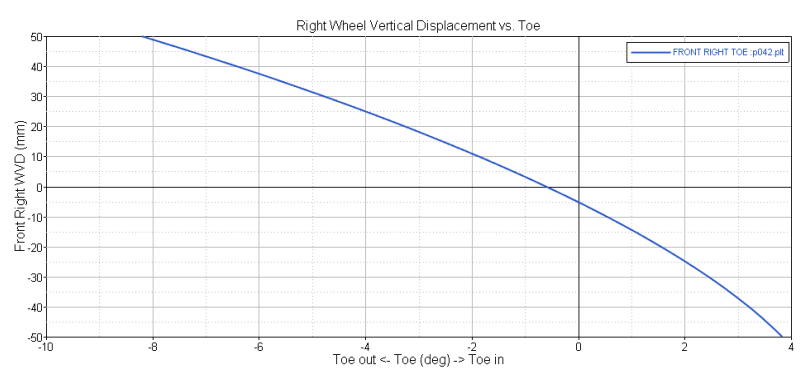

(b) Front right wheel vertical displacement (WVD) vs toe

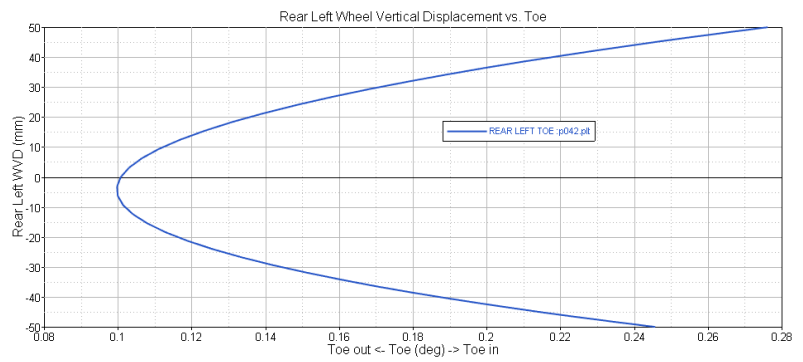

(c) Rear left wheel vertical displacement (WVD) vs toe

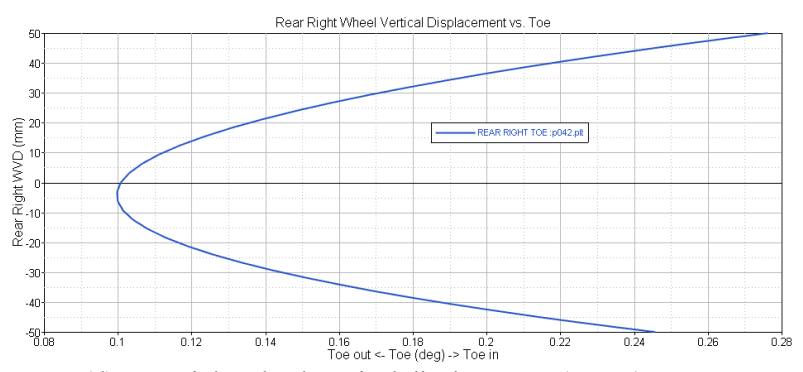

(d) Rear right wheel vertical displacement (WVD) vs toe

Figs. 6. Toe vs wheel vertical displacement

All wheels show the similar trends of camber data.

For the front wheel, the camber during maximum jounce, maximum rebound, and static height are $-1.40^{\circ}$ (negative camber), $1.10^{\circ}$ (positive camber), and $-0.25^{\circ}$ (negative camber), respectively. While for the rear wheel, the camber during maximum jounce, maximum rebound, and static height are $-3.00^{\circ}$ (negative camber), $2.75^{\circ}$ (positive camber), and $-0.01^{\circ}$ (negative camber), respectively. For both the front and rear wheels, the camber does not seem to follow the good C shape camber performance curve for SLA suspension.

The linear pattern as in Figures 7(a)-(d) matches the MacPherson type suspension, which is not suitable for racing. A minimal negative camber angle is important, especially during cornering. It gives stability to the car and improves the tire grip during cornering.

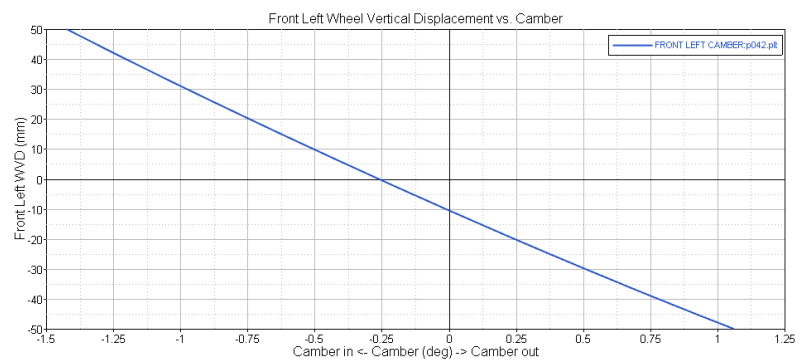

(a) Front left wheel vertical displacement (WVD) vs camber

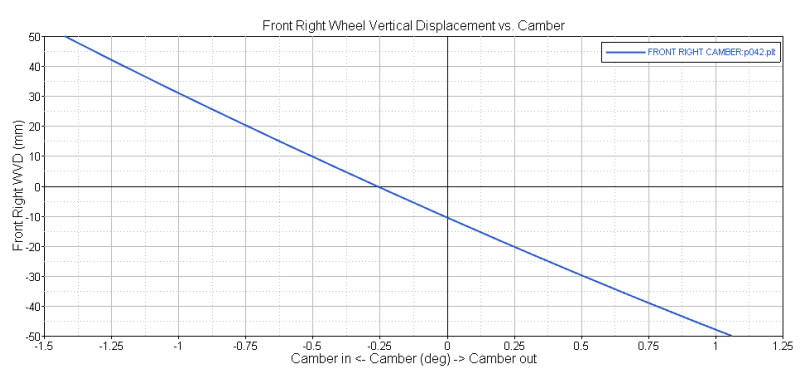

(b) Front right wheel vertical displacement (WVD) vs camber

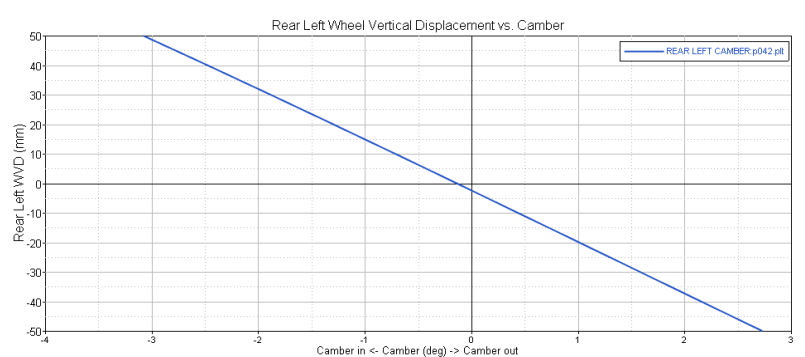

(c) Rear left wheel vertical displacement (WVD) vs camber

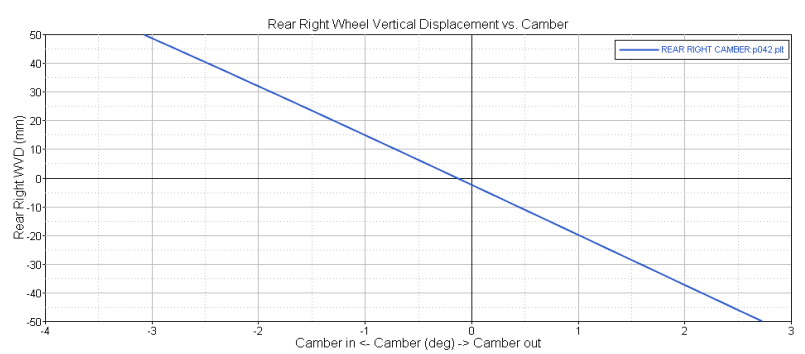

(d) Rear right wheel vertical displacement (WVD) vs camber

Figs. 7. Camber vs wheel vertical displacement

For better understanding, take a left turn situation as an example. The camber value of the left wheel decreases, making it gain a more negative camber.

In reality, during cornering, the roll action of the vehicle body makes the camber angle becomes near zero.

Thanks to the SLA control arm, the negative camber can be maintained during cornering, thus this maintains the tire grip.

\section{III.3. Roll vs Toe Analysis}

In this analysis, there are several terminologies that need to be understood. The left roll means the body rotates counter clockwise (car is observed from behind), while the right roll is the opposite of it.

The maximum jounce of the left wheel is achieved during the maximum left roll. 
Whereas the maximum rebound of the left wheel is achieved during the maximum right roll. During zero roll, maximum left roll, and maximum right roll, the toe value is similar to the value in Figs. 6. This test is performed to verify the ride test analysis result. Figs. 8 clearly show how the toe angle changes during body roll.

\section{III.4. Roll vs Camber Analysis}

Figs. 9 show the other view of camber change due to body roll. For the front left wheel, the maximum camber is achieved when the body is rolled to the right, while a minimum camber occurs during the left body roll. This condition is symmetry to the right wheel. An analysis shows that the performance of both front and rear suspension rolls is not good.

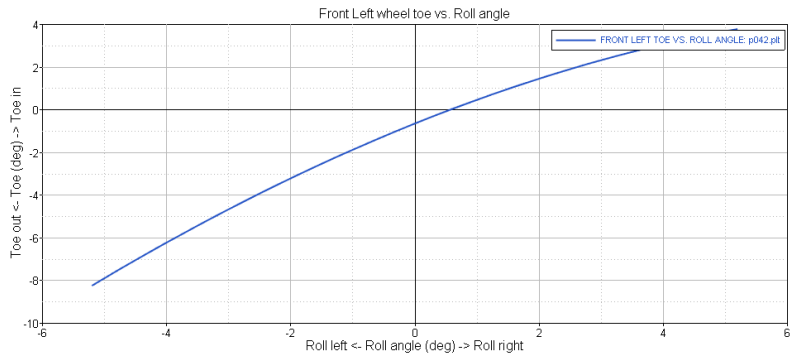

(a) Front left wheel vs roll angle

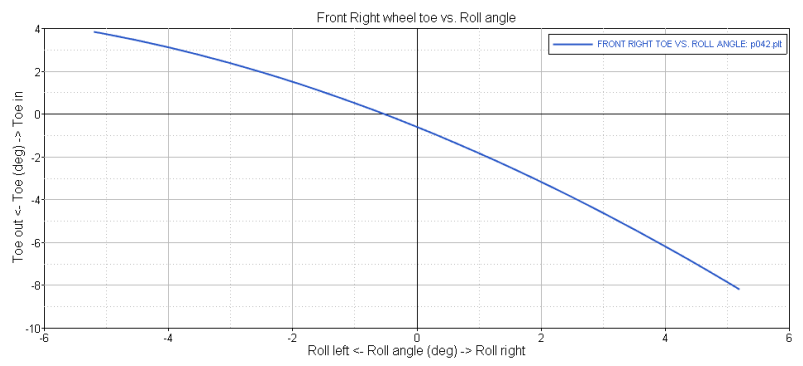

(b) Front right wheel vs roll angle

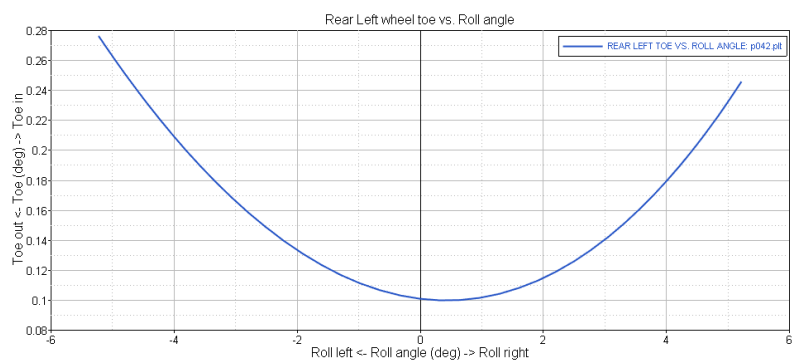

(c) Rear left wheel vs roll angle

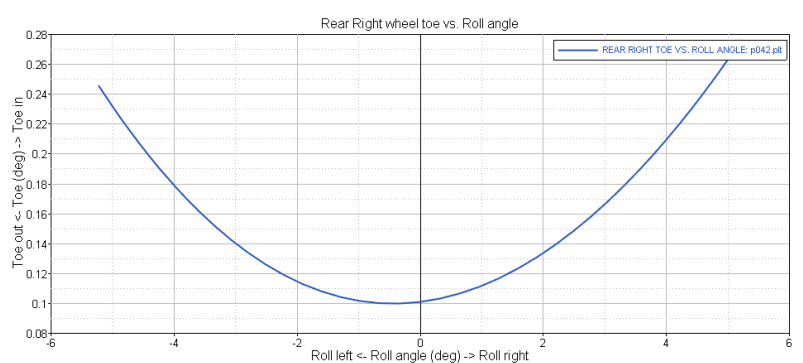

(d) Rear right wheel vs roll angle

Figs. 8. Toe vs roll angle
During cornering (jounce and rebound), the camber shows a positive camber rather than a negative camber.

A positive camber will reduce the wheel grip because the wheel tends to float from the road surface. The car is not capable to perform high speed acceleration due to the lack of wheel grip. This will reduce forward acceleration.

An increase in car speed will lead to excessive slip and can cause the car to roll over.

\section{III.5. Force on Wheel Analysis}

For the front wheel force analysis, Figs. 10(a), (b) show that the vertical force during maximum jounce, static height, and maximum rebound are $5000 \mathrm{~N}, 3500 \mathrm{~N}$, and $1500 \mathrm{~N}$, respectively. While for the rear wheel (Figs. 10 (c), (d) 0 , the vertical force during maximum jounce, static height, and maximum rebound are $4500 \mathrm{~N}, 2500 \mathrm{~N}$, and $250 \mathrm{~N}$, respectively.

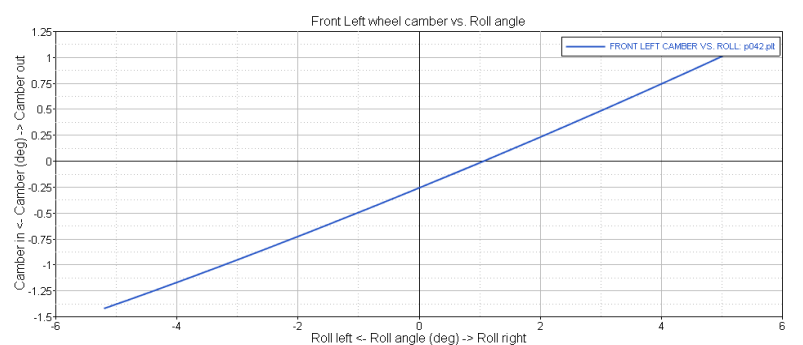

(a) Front left wheel camber vs roll angle

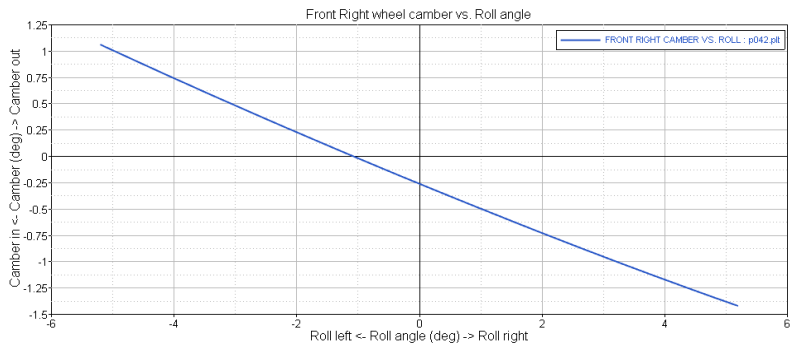

(b) Front right wheel camber vs roll angle

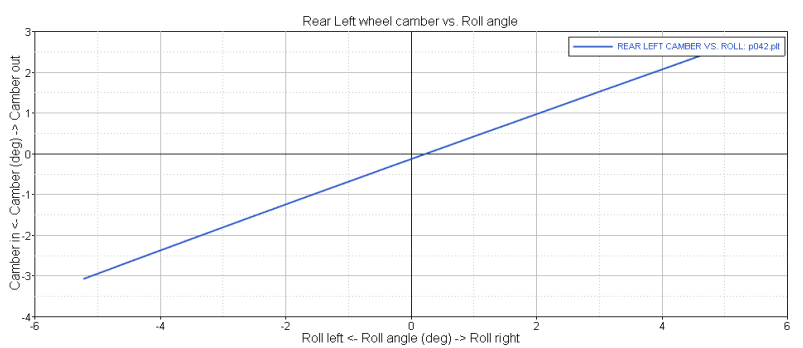

(c) Rear left wheel camber vs roll angle

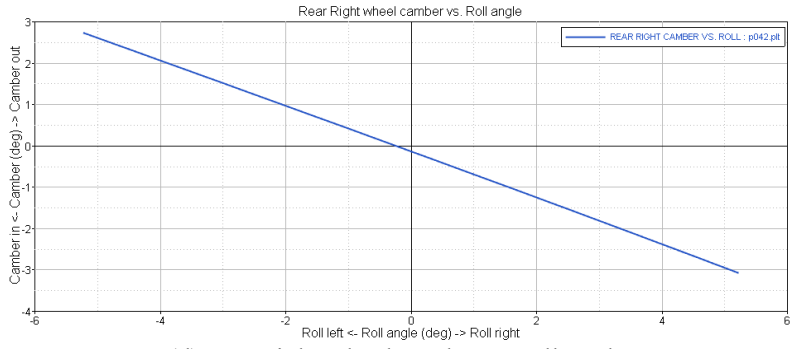

(d) Rear right wheel camber vs roll angle

Figs. 9. Camber vs roll angle 


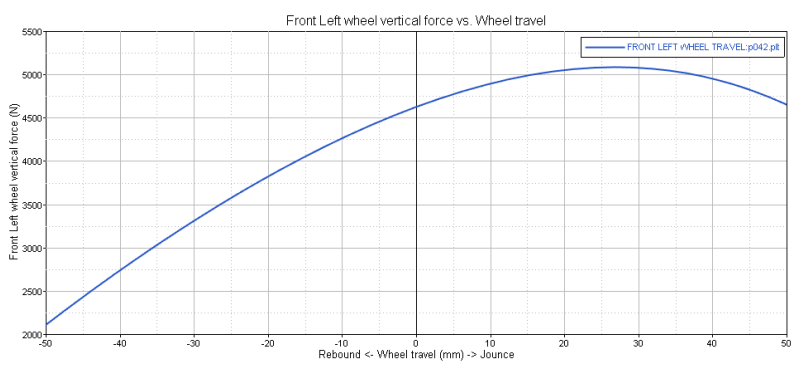

(a) Front left wheel vertical force vs wheel travel

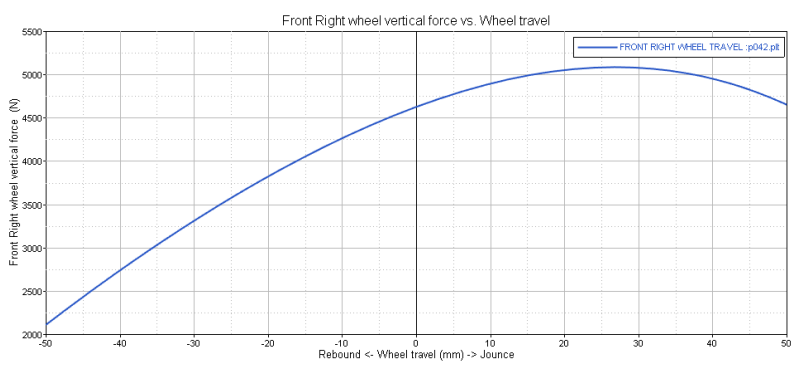

(b) Front right wheel vertical force vs wheel travel

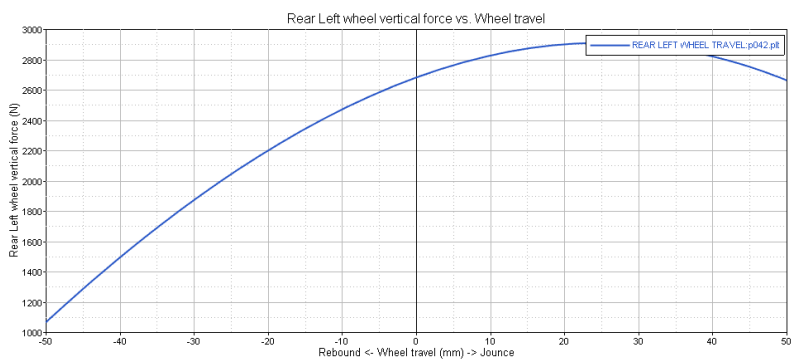

(c) Rear left wheel vertical force vs wheel travel

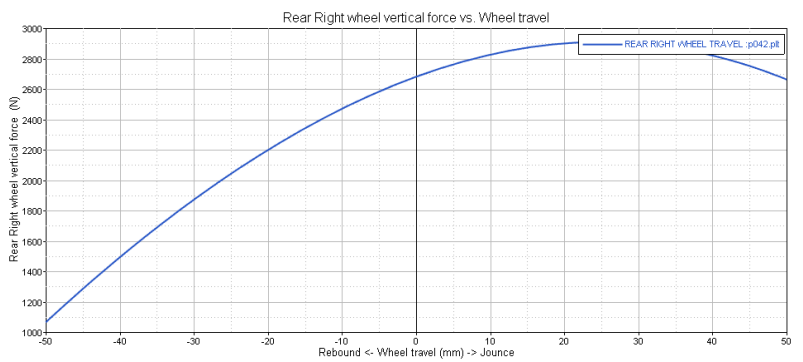

(d) Rear right wheel vertical force vs wheel travel

Figs. 10. Vertical force vs wheel travel

This clearly shows that the maximum vertical force exerted on the wheel is $5000 \mathrm{~N}$ or similar to $500 \mathrm{~kg}$ of load. The total vehicle weight is only $200 \mathrm{~kg}$, therefore, an additional $300 \mathrm{~kg}$ of force is exerted on the vehicle due to acceleration and braking.

The result from this analysis is critical as it will determine the optimum spring stiffness and damping.

From the result, the front suspension needs more stiff springs as compared to the rear suspension.

\section{Conclusion}

The main goal of the current study was to investigate the kinematic performance of a racing car suspension system. The overall performance shows that the front suspension needs design improvement.
However, the kinematics of the rear suspension system are good. The current geometry configuration for the rear suspension can be used in this car.

The analysis of the computed result shows the following:

1) The toe curve for the front wheel does not follow the good C shape toe curve design for SLA suspension. During cornering, the front wheel will toe out, which will reduce the tire grip. However, for the rear wheel, the toe curve follows the good $\mathrm{C}$ shape toe curve for SLA suspension.

2) The camber curve for the front and rear wheels does not show the good $\mathrm{C}$ shape camber curve design for SLA suspension. The tire grip is reduced during cornering, thus it increases the possibility of excessive slip to the car during high speed cornering.

3) The vehicle is not stable during roll. The toe is slightly out and the camber is positive during cornering. Hence, this will reduce the tire grip during high speed cornering.

4) The front wheel exerts vertical forces up to $5000 \mathrm{~N}$ per wheel (during cornering). Hence, the suspension frame must be able to handle a load up to $500 \mathrm{~kg}$ during cornering.

The result of this study indicates that the front suspension design must be optimised. The performance results of toe, camber, and roll for the front wheel clearly show that the current suspension design is not capable to provide maximum grip during the race.

Further research might explore the redesign of the front suspension geometry. These include improving the control arm dimensions and repositioning the front suspension hard points. The redesign process should use a proper optimisation process that will lead to the optimum SLA suspension performance.

\section{Acknowledgements}

The authors would like to acknowledge Universiti Teknikal Malaysia Melaka (UTeM) under Short Term Grant Scheme (PJP/2014/FTK(6A)/S01310) and Ministry of Higher Education (MOHE) under RAGS Grant Scheme (RAGS/2013/FTK/TK07/01/B00045) for supporting and funding this research activity.

\section{References}

[1] F. M. 2015 Committee, "FV Malaysia 2015 Vehicle Technical Specifications," 2015.

[2] B. a Jawad and B. D. Polega, "Design of Formula SAE Suspension Components," Engineering, vol. 1, no. 724, pp. 1-10, 2002.

[3] D. Woods and B. Jawad, "Numerical design of racecar suspension parameters," SAE Trans., no. 724, 2000.

[4] B. Lacroix, P. Seers, and Z. Liu, "A Passive Nonlinear Damping Design for a Road Race Car Application," Engineering, 2006.

[5] I. F. Kozhevnikov, "Vibrations of a rolling tyre," J. Sound Vib., vol. 331, no. 7, pp. 1669-1685, Mar. 2012.

[6] G. Yin and X. Jin, "Cooperative control of regenerative braking and antilock braking for a hybrid electric vehicle," Math. Probl. Eng., vol. 2013, 2013.

[7] J. D. Setiawan, M. Safarudin, and A. Singh, "Modeling, 
simulation and validation of 14 DOF full vehicle model," Int. Conf. Instrumentation, Commun. Inf. Technol. Biomed. Eng. 2009, pp. 1-6, Nov. 2009.

[8] Y. C. Chen, P. Y. Tsai, and I. A. Lai, "Kinematic Analysis of Roll Motion for a Strut / SLA Suspension System," World Acad. Sci. Eng. Technol., vol. 6, no. 5, pp. 1122-1126, 2012.

[9] E. Zapletal, "Balanced Suspension," SAE Pap. 2000-01-3572, no. $724,2000$.

[10] M. Z. Hassan, M. Z. A. Manaf, M. S. Halid, M. N. Alehan, and A. S. M. Isa, "UTeM's Amphibious Hybrid Vehicle: Ride and Handling Analysis," Appl. Mech. Mater., vol. 393, pp. 354-359, Sep. 2013.

[11] J. D. Langdon, J. Langdon, and S. Southward, "Design and Adaptive Control of a Lab-based , Tire-coupled , Quarter-car Suspension Test Rig for the Accurate Re-creation of Vehicle Response by Design and Adaptive Control of a Lab-based , Tirecoupled , Quarter-car Suspension Test Rig for the Accurate Re," Control, 2007.

[12] J. Hurel, A. Mandow, and A. García-Cerezo, "Kinematic and dynamic analysis of the McPherson suspension with a planar quarter-car model," Veh. Syst. Dyn., vol. 51, no. September 2014, pp. 1422-1437, 2013.

[13] J. S. Hwang, S. R. Kim, and S. Y. Han, "Kinematic design of a double wishbone type front suspension mechanism using multiobjective optimization," Proc. 5th ACAM Australas. Congr. Appl. Mech., no. December, pp. 788-793, 2007.

[14] L. L. Thompson, P. H. Soni, S. Raju, and E. H. Law, "The Effects of Chassis Flexibility on Roll Stiffness of a Winston Cup Race Car," Mot. Eng. Conf. Expo., no. 724, 1998.

[15] M. Burgess, N. P. F. M. Wootton, and S. Williams, "A Tool for Rapid Vehicle Suspension Design," SAE Mot. Eng. Conf., no. $724,2004$.

[16] S. Kakria and D. Singh, "CAE Analysis, Optimization and Fabrication of Formula SAE Vehicle Structure," 2015.

[17] H. Hsu, C. Coker, and H. Huang, "Optimization of an Electric Vehicle Suspension System Using CAE," vol. 4, pp. 1-5, 2010.

[18] H. W. Kim and W. S. Yoo, "MBD applications in design," Int. J. Non. Linear. Mech., vol. 53, pp. 55-62, 2013.

[19] S. Kakria, I. Sriharsha, and M. Wagh, "Modeling and simulation study of BAJA SAEINDIA all terrain vehicle (ATV) using integrated MBD-FEA approach," 14th Symp. Int. Automot. Technol. SIAT 2015, 2015.

[20] Terzo, M., Timpone, F., The control of the handling of a front wheel drive vehicle by means of a magnetorheological differential, (2013) International Review of Mechanical Engineering (IREME), 7 (3), pp. 395-401.

[21] Rajeswari, K., Lavanya, S., Lakshmi, P., Modified grey fuzzy logic controller for vehicle suspension system, (2014) International Review of Mechanical Engineering (IREME), 8 (1), pp. 153-161.

[22] Prabu, K., Jancirani, J., John, D., Dynamic characteristic analysis on half car electro pneumatic suspension system, (2013) International Review of Mechanical Engineering (IREME), 7 (3), pp. 436-441.

[23] M. Kodati, "Kinematic Analysis of the Double Wishbone Suspension System," Proc. 1st Int. 16th Natl. Conf. Mach. Mech., pp. 562-567, 2013

[24] E. R. Andersen, C. Sandu, and M. Kasarda, "Multibody Dynamics Modeling and System Identification for a Quarter-Car Test Rig with McPherson Strut Suspension Multibody Dynamics Modeling and System Identification for a Quarter-Car Test Rig with McPherson Strut Suspension," Constraints, 2007.

[25] D. M. Goelke, "Practical Aspects of Multi-Body Simulation with Hyperworks." The HyperWorks University Team.

\section{Authors' information}

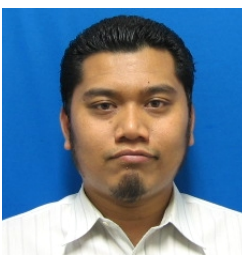

Muhammad Zaidan Abdul Manaf is currently a lecturer at the Department of Mechanical Engineering Technology, Faculty of Engineering Technology, Universiti Teknikal Malaysia Melaka (UTeM). He received his first degree from Universiti Sains Malaysia in Aerospace Engineering in 2005. Later in 2012, he received his Master's Degree in Mechanical Engineering from Universiti Kebangsaan Malaysia. He is now focusing on mechanical hybrid propulsion system and vehicle suspension design.

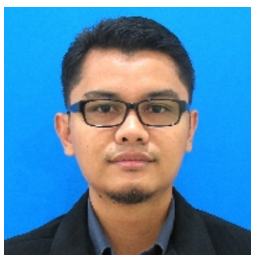

Mohd Faruq Abdul Latif is currently a lecturer in the Department of Mechanical Engineering Technology, Faculty of Engineering Technology, Universiti Teknikal Malaysia Melaka (UTeM). His current research subjects include vehicle aerodynamic and CFD. His past experience as a Mechanical Design Engineer in a consumer product manufacturer well balances his current research interests. In 2007, he graduated from UTeM with a Bachelor of Mechanical Engineering (Design \& Innovation) with honors. Later in 2014, he received his Master's Degree in Mechanical Engineering from Universiti Kebangsaan Malaysia.

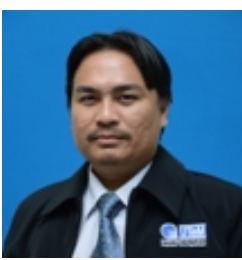

Mohd Suffian Ab Razak is currently a teaching engineer in the Department of Mechanical Engineering Technology, Faculty of Engineering Technology, Universiti Teknikal Malaysia Melaka (UTeM). He graduated from Kobe University, Japan with a Bachelor's degree in Mechanical Engineering. Previous experience working with Malaysia's national car maker, PROTON, stimulates his passion for automotive design and simulation.

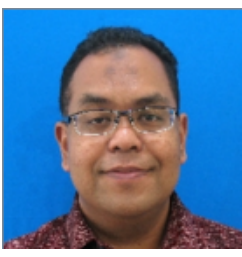

Muhammad Zahir Hassan is currently a Senior Lecturer at the Department of Mechanical Engineering Technology, Faculty of Engineering Technology, Universiti Teknikal Malaysia Melaka (UTeM). He graduated with a degree in Mechanical and Aerospace Engineering from Seoul National University, an M.Sc. in Automotive Engineering from Conventry University, and a PhD in Mechanical Engineering from the University of Leeds. He has published more than 50 papers in refereed journals, proceedings, and book chapters.

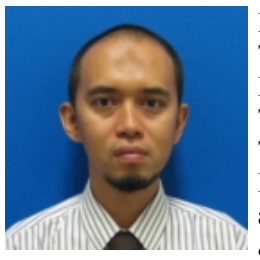

Mohd Idain Fahmy Rosley is currently a Teaching Engineer (Mechanical) at the Department of Mechanical Engineering Technology, Faculty of Engineering Technology, Universiti Teknikal Malaysia Melaka (UTeM). He graduated from UTeM with a Bachelor of Mechanical Engineering (Design \& Innovation) with honors in 2007. His past seven years of experience are in product $R \& D$ as a Senior Mechanical Design Engineer in a consumer product manufacturer. 